\title{
COST AND BENEFIT ANALYSIS OF SPORTS TOURISM IN DOWNHILL TREK, CIKOLE LEMBANG, BANDUNG BARAT DISTRICT, WEST JAVA PROVINCE
}

\author{
Hery Sigit Cahyadi ${ }^{1}$, Herlan Suherlan*2, Muhammad Aldo Dewantara ${ }^{3}$ \\ Sekolah Tinggi Pariwisata Bandung² \\ Email: contact@stp-bandung.ac.id
}

\begin{abstract}
The purpose of the research is to analyze the cost and benefit analysis and find out the feasibility of sport tourism development at Cikole, Lembang in support the lacal community income. This research was conducted at the Downhill Track Cikole Bike Park in Lembang District and is a tourist attraction in the form of downhill bicycle track facilities. The number obtained is the result of calculating the comparison between benefits and costs and shows the value that can be defined as a feasible activity, because the numbers obtained have a value of more than 1 which is an indication of eligibility with a results in the form of 1 declared feasible and if $<1$ (less of) is declared ineligible. Based on the calculation results of the Cost-Benefit Ratio (CBR) analysis with the final result in the form of a comparison value of $\mathbf{3 , 3 1 2 8 5 2 8 .}$. With the increase in the number of visits and opening of new jobs, the results of the analysis in the form of downhill activities have been declared feasible.
\end{abstract}

Keywords: Cost Benefit Analysis; Cost Benefit Ratio; Benefit; Cost; Feasibility.

\section{A. INTRODUCTION}

Sport tourism is a relatively new and ever increasing industry in the tourism industry focusing on the target planning of developing countries. It is also believed that sport tourism shall restructure the rural and urban communities from social and economic perspectives. Seemingly, sport tourism shall improve the individuals' life quality through tourist attraction and results in the economic welfare of the local communities (Swart and Bob, 2007; Higham, 2018; Turco, Swart, Bob, Moodley, 2003). Sport tourism is defined as a temporary movement from a person's settlement to pass their free time playing and watching games and so forth (Preuss et al., 2007). Today, sport and tourism are concerned with the important economic activities in the developed and developing nations (Swart and Bob, 2007).

There are two kinds of sport tourisms: the first one employs sport for the sake of its tourism development advantages, while the other one is the result of sportbased activities (Tassiopoulosa and Haydamb, 2007). So the communities should take both types into account (Daniels, 2007) so as to optimally take advantage of their positive results. Since there are various motives for involvement in sport activities, such as competition, recreation and traveling to watch preliminary or premier competitions or sport attractions (Tassiopoulosa and Haydamb, 2007), the natural resources of sport and tourism facilities play a significant role in attracting tourists to the host city, region or country. In some of countries $25 \%$ of total tourism revenue is related to sport and because of its economic and political role this is important applied issue. Gibson (1998), and Gammon and Robinson (2003) considered tourism and sporting in a wide range of human activities in natural, which is also due to the vast amount of natural attractions of the sport in the country and can serve as an important source of increased level of sports tourism in the country (although in the tourism and sports tourism in the past). The system as well as the tourist attraction Hinch and Higham (2011), according to numerous studies in various aspects of multilateral overt and covert sports tourism as well as to represent. Various goals include properties attraction and capabilities of tourism and sport to develop and attract sport tourism; 
therefore, sport and tourism are two critical elements of global economy that affected modern society developing sport activities and coordination between sport and tourism benefits. Sport tourism term was innovated to create better understanding about sport as tourism motivation. According to world tourism organization statistics $43 \%$ of world occupation is related to tourism industry. For example, during 1997 to 2005 , sport tourism lead to annual $13 \%$ increase of national gross production that is as a result of economic activities. According to holding great sport competitions, annual 19\% unemployment decreases had been achieved. According to above issues, statistics show most of world countries have appropriate condition about sport tourist and manage great part of their economies through sport tourism economy.

In the twentieth century there has been a rapid development in terms of sports and tourism, then it became one of the reasons tourists do tourism activities and is the fastest growing sector at this time (Higham, 2005). In addition, the phenomenon of the existence of the community in sports tourism activities has a close relationship with tourist activities. In a study by Nunn and Rosentraub (1997) on sports activities in areas belonging to local communities where sporting events were held, concluded that the expected benefits from the existence of sports tourism were hardly enjoyed by the local community. New job opportunities are not generated as jobs or services that are usually associated with implementing tourism activities.

Sports tourism requires a place in carrying out sports activities that can involve various elements of interest and provide knowledge of the risk of damage to the surrounding community, so the utilization needs to be measured by the amount of costs and the level of benefits generated. Costs incurred are the overall costs that affect the calculation of benefit-cost analysis, tourism activities and their relationship with the existence of the community to support economic growth in an area by providing new jobs and income for the village, by seeing the benefits in the economic sector making sports tourism a one potential sector (Higham, 2005).

This study aims to assess and measure whether the activities carried out really have a positive impact on actors and stakeholders, namely by conducting research on the analysis of cost benefits by comparing the benefits gained with the total expenditure in an activity. According to Dunn (2003) in evaluating an activity can be done by measuring the level of benefits from the results of activities that have been running to assess the ratio by comparing total income and total expenditure by using the method of cost benefit analysis. The evaluation used is to use secondary data from the management as a stage of data analysis using BCR (Benefit Cost Ratio) analysis. BCR analysis makes it possible to see a comparison between the amount of benefits and costs for a project. Cost benefit analysis methods are often used in analyzing the sustainability of government programs and projects. Implementation of a project that generally has a goal that is not profit-oriented like a private company project. In other words, the goal is based on general benefits that can be felt and obtained by the community.

\section{B. METODE PENELITIAN/RESEARCH METHOD}

This research uses a quantitative approach with the Cost Benefit Analysis method. Interviews with the purposive sampling method (Arikunto, 2010; Bogdan dan Taylor, 2012; Creswell, 2010) were conducted to PT. Perhutani and the community involved in tourism management in Cikole.

This study aims to determine the value of benefits and costs of sports tourism activities in Cikole Downhill Track. Using the cost benefit analysis method, namely: Cost Benefit Ratio (CBR). The BCR method is done by calculating the comparison of all the benefits that can be identified during the life of the planned investment with the total costs incurred during the project implementation. BCR calculations can be done using the following formula:

$$
B C R=\frac{\sum B t /(1+i)^{t}}{\sum C t /(1+i)^{t}}
$$

$\mathrm{BCR}=$ Benefit Cost Ratio

$\sum \mathrm{Bt}=$ Total Benefit

$\sum \mathrm{Ct}=$ Total Cost 
Based on the calculation of Benefit Cost Ratio (BCR), the following hypothesis will be obtained:

If $\mathrm{BCR}>1$, then it can be interpreted that sports tourism activities in Cikole Downhill Track are feasible to be carried out.

If $\mathrm{BCR}<1$, it can be interpreted that sports tourism activities in Cikole Downhill Track are not feasible to run.

\section{RESULTS AND ANALYSIS}

Trek Downhill Cikole is located in Cikole Village, Lembang District, West Bandung Regency and is in the area of land belonging to Perhutani, North Bandung Regency. The village area with an area of $8.06 \mathrm{~km}^{2}$ is widely used as a tourism location with a lot of hilly land which is proven to be one of the most popular destinations in West Java. Entering early 2000, Lembang developed the tourism sector by utilizing the conditions and its cool and hilly area to become the location of tourism activities. One of them is the Cikole Cluster area which is planned to be the location of tourism activities that have benefits to the community from forest management and integrated tourism activities. With a total available land of 640.25 hectares. Divided into 3 zones, namely Tertiary Zone, Secondary Zone and Premium Zone, all three are limited zones which can be interpreted as tourist zones, buffer zones and special zones.

Track downhill tourism revenue consists of company revenue (PERHUTANI), which has been a tourist attraction since 2000 and ticketing has only begun to take effect from 2015 through Administrative Decree No.65 of the Ministry of Environment and Forestry. With a value of Rp.10,000 / person and included with downhill (MTB) bicycles. Until 2017 until now the price has been set to be Rp. 15,000 . The intended costs include entry fees, bicycle entry fees and tourist insurance. The revenue generated by PERHUTANI through the results of ticket sales in 2016-2018 was Rp.175,935,000.

Merchant income can be seen from the total income of traders before and after the downhill tourism activities in Cikole. residents who initially relied on the agricultural sector then turned to the tourism sector as their main income. With the downhill track tourism activities, opening new access for people to get new jobs. This directly improved the economy of some of the people of Cikole Village.

The Cikole Bike Park downhill track location adjacent to Orchid Forest has a positive impact from an economic perspective because it provides opportunities to transact more with tourists who come. Cikole Bike Park as a tourist location becomes a new livelihood for the people of Cikole Village especially those who are members of the LMDH (Forest Village Community Institution) community. LMDH members who sell at Cikole Bike Park get new income from selling.

The average income of traders in Cikole Bike Park in a month is Rp. 1,250,000-Rp. 1,500,000 / in the holiday month. Whereas in the lonely months Rp.800,000-Rp.900,000. with a discount of Rp.225,000 / month paid to PERHUTANI as a sharing fee. The total income from trading results and income from downhill tourist contributions to $\mathrm{LMDH}$, and reduced by the trader sharing fee of Rp.225,000 to PERHUTANI, resulting in Rp.75,799,204. Land area of 640.25 Ha. The land can be used by the community as plantations and investors to make it a business land, has rules to continue preserving nature with the conservation program by the manager, the RHL (Protected Forest Rehabilitation) program with assistance from the center through SK.332 / Men LHK / Secretary General / DAS.0 / 7/2017.

Aiming to preserve forests by adding and extending forest quality by reforestation through planting trees divided into forestry plants and MPTS (Multi Purpose Tree Sector) which means plants that can be beneficial in all aspects and structures that can be utilized by the stem, roots to the fruit. With a composition of $1 \mathrm{Ha}$ of land, $50 \%$ of Forestry Plants and 50\% of MPTS with reference to Agroforestry standards.

The salary earned is an expense from PERHUTANI with an average of Rp. 3,500,000 / month. In addition to job opportunities available from PERHUTANI, the community was empowered by opening opportunities to sell in the front area of the Orchid Forest parking lot adjacent to Cikole Bike Park, to date there are 29 business stalls that have a written agreement with the manager to be given permission to use part of the land can be utilized by the community. The land and facilities used for selling are gifts from PERHUTANI to the LMDH community as business partners. 
The downhill investment costs at Cikole Bike Park include the cost of constructing the Cikole Classic track, the Bahenol Cikole track and the construction of facilities such as public toilets. the Cikole Bahenol downhill track was built in 2017 with a total budget of IDR 30,000,000 and IDR 25,000,000 for the Cikole Classic Track. The budget issued is funds obtained from a number of downhill lovers communities through www.kitabisa.com.

The total expenditure spent on building the Cikole Bahenol downhill track from the point of material and construction is Rp.17,845,000 plus a labor cost of 5 people with a total labor cost of Rp.6,750,000. Cikole Bahenol downhill track development is carried out on the basis of the needs and requests of downhill tourists to get variations in doing the exercises in the same place but with different terrain so as to encourage the community as the organizer to make development requests to the Forestry as the owner to build a new track namely Cikole Track Voluptuous. With a total total cost of construction is Rp.24,595,000. The total budget for the construction of the Cikole Classic Track is Rp.22,860,000 with a total budget available of Rp.25,000,000. Built with help of the bicycle community in Bandung.

Operational costs include the costs of employee salaries and the cost of pre-facilities in the form of water and electricity distributed to 29 traders in the Cikole Cluster. Maintenance costs in the form of land maintenance costs carried out directly by LMDH (Forest Village Community Institution) with funds obtained from the contribution of the withdrawal of funds from tourists who came specifically to enjoy the Cikole Bike Park downhill track at a rate of Rp.10,000 / person. The maintenance process is carried out twice a week, namely by cleaning the track track that is done by 3 workers at a cost of Rp.75,000 / person. With the following budget details:

The operational costs carried out by LMDH are to keep the land and track track downhill to keep it clean from wild leaves and plants, in maintaining the path along the 1.3 and $1.6 \mathrm{~km}$ required labor from workers and workers as many as 3 people in 1 time of land maintenance and track tracks, which are carried out at least 2 weeks maintenance. The hired workers are Cikole Village people who have free time and are members of the LMDH community. Paid by Abah as maintenance implementer. The total budget spent by LMDH in maintaining the Cikole Bahenol and Cikole Classic downhill tracks in 3 years is Rp.32,400,000. The overall operational and maintenance costs for Cikole Bike Park based on the calculation of track maintenance costs, operational costs for water and electricity bills are Rp.38,059,546.

As a PERHUTANI partner at Cikole Bike Park, to remain a business partner that sells on land that has been provided by the manager. Require each trade stall to pay fees to the manager as the cost of maintaining land and the cost of electricity and water provided as supporting facilities to the trading business in the Cikole Cluster, the fee required to be paid to the manager is Rp.225,000 / month for all business partners. The LMDH community utilizes the land provided by PERHUTANI as a tourism facility in the form of land that is used as a shop to sell on the conditions written in the Cooperation Agreement (PKS) in the form of being able to use the land and facilities provided by the manager by paying a sharing of Rp.225,000 / month, and in 3 years Rp.8,100,000 was collected from 1 trader. There are 29 traders who joined LMDH who signed the Cooperation Agreement (PKS) with PERHUTANI.

Toilets are tourist facilities funded by PERHUTANI as land owners and managers. Construction of toilet facilities consumes construction costs of the total building materials and workers' wages with a total of Rp.22,851,300. Calculation results from tourism revenue (ticketing), revenue sharing, trading income and income from track maintenance contributions. The calculated data is data from the last 3 years. Income obtained in the last 3 years, namely 2016, 2017 and 2018, was Rp.385,834,204. The cost in the Cost-Benefit Analysis calculation in this study focuses on investment costs divided into the construction costs of the Cikole Bahenol and Cikole Classic downhill tracks, operational and maintenance costs, merchant costs and facility construction costs in the form of toilets and theh results are:

$4 \longdiv { \text { Jurnal Kepariwisataan: Destinasi, Hospitalitas dan Perjalanan, Volume } 5 \text { Nomor 1, 2021: 1-9 } }$ 
Table 1. TOTAL BENEFIT

\begin{tabular}{lcrrr}
\hline \multicolumn{5}{c}{ Revenue and Benefit } \\
\cline { 1 - 4 } Year & Sharing & \multicolumn{1}{c}{ Ticket } & Sales and Trek Maintenance & Job Opportunity \\
\hline 2016 & 2.700 .000 & 49.230 .000 & 23.595 .321 .60 & 126.000 .000 \\
\hline 2017 & 2.700 .000 & 59.490 .000 & 25.231 .215 .40 & \\
\hline 2018 & 2.700 .000 & 67.215 .000 & 26.972 .667 .34 & \\
\cline { 1 - 4 } Total & 8.100 .000 & 175.935 .000 & 75.799 .204 & \\
\hline Rp.385.834.204 & & & \\
\hline
\end{tabular}

Source: KPH Perhutani, 2019

Table 2. TOTAL COST

\begin{tabular}{ccccc}
\hline \multicolumn{5}{c}{ Cost (Rp.) } \\
\hline $\begin{array}{c}\text { Trek } \\
\text { Downhill } \\
\text { Development }\end{array}$ & Facilities & $\begin{array}{c}\text { Merchant } \\
\text { Sharing }\end{array}$ & $\begin{array}{c}\text { Operational \& } \\
\text { Maintenance }\end{array}$ & Total \\
\hline 47455000 & $22,851,300$ & $8,100,000$ & $38,059,546$ & $116,465,846$ \\
\hline
\end{tabular}

Source: Researcher Calculation, 2019

Costs data source was taken for the last 3 years, 2016, 2017 and 2018. Until the final results obtained from the total expenditure on the Cikole Bike Park is Rp.116,465,846. Cost Benefit Analysis or also benefit and cost analysis is a calculation made based on data obtained and is data that describes the actual conditions of the total calculation (Mangkoesoebroto, 2000). Benefits consist of revenue and income obtained by the manager which is divided into PERHUTANI, LMDH and the bicycle community. Data from the calculation of benefits are then compared with data from the calculation of costs divided into investment costs, operational costs, trader costs and facility construction costs.

Table 3. BENEFIT AND COST CALCULATION

\begin{tabular}{|c|c|c|c|}
\hline No & Cost and Benefit & Calculation & Total \\
\hline 1 & Tourism Revenue & Ticketing 2016-2018 & Rp.175.935.000 \\
\hline 2 & Sharing for Perhutani & Rp.225.000/1 seller x 1 x 3 years & Rp.8.100.000 \\
\hline 3 & $\begin{array}{l}\text { Revenue from kiosk and } \\
\text { maintenance }\end{array}$ & $\begin{array}{l}\text { Rp.40,714,537.50 + Rp.43,184,667 } \\
2016-2018\end{array}$ & Rp.83.899.204 \\
\hline 4 & Job opportunity & 5 staff $x$ Rp. $3.500 .000 \times 12$ month & Rp.126.000.000 \\
\hline 5 & Trek Development & $\begin{array}{l}\text { Cikole Bahenol (Rp.24.595.000) + } \\
\text { Cikole Klasik (Rp.22.860.000) }\end{array}$ & - Rp.47.455.000 \\
\hline 6 & Facilities Development & Toilet Development & - Rp.22.851.300 \\
\hline 7 & Sharing cost & Rp.2.700.000 x 3 (2016-2018) & - Rp.8.100.000 \\
\hline 8 & $\begin{array}{l}\text { Operational spending \& } \\
\text { maintenance }\end{array}$ & $\begin{array}{l}12 \text { workers x } 12 \text { month } \times 3 \text { periods } \\
(32,400,000)+\text { electricity cost } \\
(3,153,946)+\text { water }(2,505,600) .\end{array}$ & - Rp.38.059.546 \\
\hline 9 & $\begin{array}{l}\text { Environmental awareness } \\
\text { and reforestation } \\
\text { improvement program }\end{array}$ & (no calculation) & 0 \\
\hline \multicolumn{2}{|c|}{ Total Cost } & \multicolumn{2}{|c|}{ Rp. 116.465.846 } \\
\hline \multicolumn{2}{|c|}{ Total Benefit } & \multicolumn{2}{|c|}{ Rp.385.834.204 } \\
\hline
\end{tabular}

Source: Researcher Calculation, 2019

Data obtained from the results of benefits and costs are then calculated using the concept of Cost Benefit Ratio with calculations and results with the formula: 


$$
\begin{gathered}
B C R=\frac{\sum B t /(1+i)^{t}}{\sum C t /(1+i)^{t}} \\
B C R=\frac{385834204 /(1+0.10)^{3}}{116465846 /(1+0.10)^{3}}
\end{gathered}
$$

\section{$\mathrm{BCR}=\mathbf{3 , 3 1 2 8 5 2 8}$}

Downhill sports tourism activities in the Cikole Bike Park with an initial investment value in the construction of the Cikole Bahenol and Cikole downhill tracks is Rp.47,455,000 which was built in 2005 and 2017 and so far over the past 3 years, it has spent operational and maintenance funds based on bill costs water and electricity and land maintenance carried out by the community who are members of the Cikole Village LMDH community in carrying out downhill activities in the Cikole Bike Park, which is Rp.38,059,546.

Most people who are members of LMDH get the opportunity to get work and additional income from the opportunity to have a business in the Cikole Bike Park parking area with a Cooperation Agreement (PKS) between the seller and PERHUTANI which requires paying the sharing fee to the manager and has spent funds from 1 stall that specifically handles downhill tourists for 3 years as much as Rp.8,100,000 which is paid regularly every month. Traders who have the right to sell and sign a Cooperation Agreement with PERHUTANI are given facilities in the form of land and business buildings that are provided with additional facilities in the form of lighting with 15 watt lamps that can be used freely by the seller. While additional facilities in the form of clean water were provided as a support for toilet facilities that had been built by PERHUTANI with a total development fund of Rp.22,851,300. In the aspect of benefits, the value obtained from the calculation results with a total value of Rp.259,834,204. The result is a calculation of the total revenue obtained from the sale of entrance tickets to Cikole Bike Park in 3 years, namely 2016, 2017 and 2018 with the total revenue from the sale of entrance tickets is Rp.175,935,000.

In 2016 after the holding of PORNAS, the downhill championship committee built facilities in the form of buildings that functioned as athletes' changing rooms, after the championship was over, the buildings that had been built were donated and used as buildings to sell, one of which is by providing business stalls to provide new opportunities for the community to get a job, from the results of calculations done to 1 trader who is also responsible for carrying out maintenance and maintenance of downhill bicycle tracks and lanes with a total income of Rp.75,799,204. With the community utilizing the building provided by the government after holding the championship in 2016 as a business stall, providing a certain amount of income for PERHUTANI as the manager of the results of sharing paid by traders for 3 years, namely Rp.8,100,000. The existence of downhill sports tourism activities in Cikole Bike Park has a positive impact that can directly show the side effects of economic growth in an area from the results of tourism activities. From the indicators studied, the reforestation program and improvement of environmental awareness, tourism income, supporting infrastructure expenditure, investment costs, maintenance costs, operational costs and construction of facilities.

Analysis results that show the feasibility of the Cikole Bike Park Dowhill track can be an effort for managers to be able to continue the development of the tourism sector in the form of greater benefits than the costs incurred, providing welfare for managers and surrounding communities so that the management of the area can be more efficient, more efficient expenditure can bring resources to be used better in improving the quality of the track downhill from the aspect of attraction. These resources refer to financial assets where the management of downhill tracks can be developed by focusing on hiring personnel in the field of track operations and track development.

6 Jurnal Kepariwisataan: Destinasi, Hospitalitas dan Perjalanan, Volume 5 Nomor 1, 2021: 1-9 


\section{CONCLUSION}

The Cikole Bike Park downhill track has now demonstrated the feasibility of implementing downhill sports tourism. The variable is considered to have been able to show the feasibility, with the downhill tourism activities found a phenomenon in the form of opening new jobs for the surrounding community and downhill sports facilities for tourists so as to increase the number of visits from year to year. With the increase in the number of visits and opening of new jobs, the results of the analysis in the form of downhill activities have been declared feasible.

The results of total profit based on the calculation of benefits and costs, provide benefits as much as Rp.385,834,204. The amount is a calculation of ticket sharing, selling income, income from repairs and maintenance and income from employment. The results of the sum have a greater value than the costs incurred in managing the downhill track.

The calculation of costs based on the sum of the Cikole Bahenol and Cikole Classic track construction, construction of facilities in the form of toilets, sharing of costs of trading to Perhutani and costs of repairs and management (maintenance and operations) is Rp.116,465,846. The amount produced has a lower value compared to the total number of benefits obtained.

The results obtained with the results that if the BCR value calculation results are more than 1 , it can be interpreted that sports tourism activities in Cikole Downhill Track are feasible to be carried out. But if the BCR value is less than 1, it can be interpreted that sports tourism activities in the Cikole Downhill Track are not feasible to run. Based on the results obtained from the calculation of the Cost Benefit Ratio (BCR) analysis, the results in the form of $\mathrm{BCR}$ are more than 1 , which is the calculation result shows that the figure is 3,3128528 which means that the downhill sports tourism activities are considered feasible from the BCR criteria.

\section{REFERENCES}

\section{Journal Article:}

Asmara \& Suhirman. (2014). Persepsi dan Sikap Masyarakat Terhadap Kegiatan Ekowisata Kampung Cikindang, Desa Langensari Kecamatan Lembang, Kabupaten Bandung Barat. Jurnal Perencanaan Wilayah dan Kota.

Chappelet, J.; Junod, T. A tale of 3 Olympic cities: What can Turin learn from the Olympic legacy of other alpine cities? In Proceedings of the Workshop on Major Sport Events as Opportunity for Development, Valencia, Spain, 14-16 June 2006; pp. 83-90.

Cornelissen, S.; Bob, U.; Swart, K. Towards redefining the concept of legacy in relation to sport megaevents: Insights from the 2010 FIFA World Cup. Dev. South. Afr. 2011, 28, 307-318.

Daniels MJ (2007)." Central place theory and sport tourism impacts“. Ann. Tourism Res., 34(2): 332-347.

Deccio, C.; Baloglu, S. Nonhost community resident reactions to the 2002 Winter Games: The spillover impacts. J. Travel Res. 2002, 41, 46-56.

Delamare, F., L., D. \& winterton, J. (2005) What is Competence?. Human Resources development International. Rotledge. Taylor and Francis Group.

Drakakis, P.; Papadaskalopoulos, A. Economic contribution of active sport tourism: The case of four sport activities in Messinia, Greece. J. Sport Tour. 2014, 19, 199-231.

Dunn, William N. (2003). Analisis Kebijakan Publik. Yogyakarta: Gadjah Mada.

Fridgen, Joseph D. (1996). Tourism and the Hospitality Industry. Michigan: Educational Institute of the American Hotel \& Motel Association.

Gammon S, Robinson T. Sport and Tourism: A Conceptual Framework. Journal of Sport \& Tourism. 
2003;8(1):216.

Gammon, S.; Robinson, T. Sport and Tourism: A Conceptual Framework. J. Sport Tour. 2003, 8, 21-26.

Gibson HJ. Sport Tourism: A Critical Analysis of Research. Sport Management Review. 1998;1(1):45-76.

Hari, A., Friatno dkk. (2014). Analisis Biaya dan Manfaat Usaha Wisata Terumbu Karang Taman Pendidikan Laut Bintang Samudera. Kendari. Jurnal Ilmu Kelautan. Universitas Halu Oleo.

Hinch, T. \& Higham, J. (2005). Sport, Tourism and Authenticity: European Sport Management Quarterly. Special Issues Theory and Method. Current Issues in Tourism, 2: 82-90.

Istari, A.(2014). Analisis Biaya Manfaat Proyek Pembangunan Melalui Program Nasional Pedesaan terhadap Peningkatan Ekonomi Lokal. Cost Benefit Journal. Kediri. Universitas Brawijaya.

Karadakis, K.; Kaplanidou, K. Legacy perceptions among host and non-host Olympic Games residents: A longitudinal study of the 2010 Vancouver Olympic Games. Eur. Sport Manag. Q. 2012, 12, 243-264.

Kurtzman, J. Sports tourism categories. J. Sport Tour. 2005, 10, 15-20.

Nadiasa, M., Maya dan Norken. (2010). Analisis investasi Pengembangan Potensi Pariwisata Pada Pembangunan Waduk Jehem di Kabupaten Bangli. Bangli. Jurnal Teknik Sipil. Universitas Udayana.

Nunn S, Rosentraub M (1997) Sport wars: Suburbs and center cities in a Zero Sum Game. Journal of Sport \& Social Issues 21 (1), 65-82.

Prasetya, Ferry. (2012). MODUL EKONOMI PUBLIK BAGIAN V: TEORI PENGELUARAN PEMERINTAH. Fakultas Ekonomi dan Bisnis Universitas Brawijaya Malang.

Preuss H, Benoit S, Norm O, Reilly K (2007)." Profiling managing sport event visitors: The 2002 commonwealth games". 12: 5-23.

Preuss, H. The conceptualization and measurement of mega sport event legacies. J. Sport Tour. 2007, 12, 207-227.

Ritchie, B.W.; Adair, D. Sport Tourism: An Introduction and Overview. In Sport Tourism: Interrelationships, Impacts and Issues; Ritchie, B.W., Adair, D., Eds.; Channel View Publications: Tonawanda, NY, USA, 2004; pp. 1-29.

Sant, S.L.; Mason, D.S.; Hinch, T.D. Conceptualising Olympic tourism legacy: Destination marketing organisations and Vancouver 2010. J. Sport Tour. 2013, 18, 287-312.।

Stephen D. Ross 2001, DEVELOPING SPORTSS TOURISM, An e Guide for Destination Marketers and Sportss Events Planners' National Laboratory for Tourism and e-commerce July 2001

Swart K, Bob U (2007)." The eluding link: Toward developing a national sport tourism strategy in South Africa beyond 2010". Politikon, 34(3): 373-391.

Tassiopoulosa D, Haydamb N (2007)." Golf tourists in South Africa: A demand-side study of a niche market in sports Tourism". Tourism Manage., 29(5): 870-882.

Tomas Hinch \&James Higbam (2004) Sportss and adventure tourism Channel view publication, United Kingdom

Tourists. J. Sport Manag. 目回回园, 24, 544-566. Standeven, J.; Deknop, P. Sport Tourism. Champaign; Human Kinetics: Champaign, IL, USA, 1999.

Turner, R. K., Pearce, David, and Bateman, Ian. (1993) Environmental Economics an Elemantry Introduction, The Johns Hopkins, University Press, Baltimore.

Tyler, B.D.; Morse, S.C.; Cook, R.K. Putting Heads in Beds: A Small Sport Event Seeks the Right Analysis to Appeal to CVBs. J. Sport Manag. 2017, 6, 10-19.

Weed, M. And Bull, C. (2009). Sport And Tourism: Participants, Policy And Providers 2nd Ed. Oxford: Elsevier Butterworth-Heinemann.

8 | Jurnal Kepariwisataan: Destinasi, Hospitalitas dan Perjalanan, Volume 5 Nomor 1, 2021: 1-9 
Zelazo, P. D., Blair, C. B., Willoughby, M. T., Larson, M., Officer, P., Higgins, E., \& Sussman, A. (2017). Executive Functio : Implications for Education Authors.

\section{Book}

Adair, J. (2004). Adair on Teambuilding and Motivation, edited by Neil Thomas. London: Thorogood Publishing Ltd.

Agus Ristono. (2013). Manajemen Persediaan. Penerbit Graha Ilmu, Yogyakarta.

Ahmadi, Abu. (2002). Psikologi Sosial. Jakarta: Rineka Cipta.

Andi Prastowo. (2012). Panduan Kreatif Membuat Bahan Ajar Inovatif. Yogyakarta: Diva Press.

Any Noor. (2013). Manajemen Event. Bandung: Alfabeta

Arikunto, S. (2002). Metodologi Penelitian Suatu Pendekatan Proposal. Jakarta: PT. Rineka Cipta.

Arikunto, S. (2010). Prosedur Penelitian Suatu Pendekatan Praktik. Jakarta: Rineka Cipta.

Bimo Walgito. (2002). Pengantar Psikologi Umum. Yogyakarta: Andi Offset.

Bogdan dan Taylor. (2012). Prosedur Penelitian. Dalam Moleong, Pendekatan Kualitatif. Jakarta: Rineka Cipta.

Choi, D.W.; Shonk, D.J.; Bravo, G. Development of a Conceptual Model in International Sport Tourism:

Creswell, John W. 2010. Research Design Pendekatan Kualitatif, Kuantitatif, dan Mixed. Pustaka Pelajar. Yogyakarta University Press.

Exploring Pre-and Post-Consumption Factors. Int. J. Sport Manag. Recreat. Tour. 2016, 21, 21-47

Guba and Yvonna S. Lincoln. (1985). Naturalistic Inquiry. California: Sage.

Hermawan Kartajaya. 2006. Hermawan Kartajaya on Segmentation Seri 9 Elemen Marketing. Bandung: PT. Mizan Pustaka.

Heydarzadeh, K. Sport Tourism; Organization of Trade Promotion of Iran: Tehran, Iran, 2007.

Idrus, M. (2009). Metode penelitian Ilmu Sosial. Yogyakarta: PT. Gelora Akasara Pratama.

Kaplanidou, K.; Vogt, C. The Meaning and Measurement of a Sport Event Experience among Active Sport Mangkoesoebroto, Guritno. (2001). Ekonomi Publik. Yogyakarta: BPFE.

Reksohadiprodjo, Sukanto dan Handoko, T. Hani. (2002). Organisasi Perusahaan Edisi Kedua, Yogyakarta : BPFE.

Spillane, James J. (2003). Pariwisata dan Wisata Budaya, CV. Rajawali.

Suparmoko dan Irawan. (2003). Ekonomika Pembangunan. Edisi keenam.

Weed, M. (2008). Sport \& Tourism A Reader. New York : Routledge.

Yogyakarta. BPFE. UGM.

\section{Internet Source}

Badan Perencanaan Pembangunan Nasional (BAPPENAS). (2018). Ekonomi dan Pembangunan. Jakarta. Situs Web Perpustakaan: www.perpustakaan.bappenas.go.id.

Kementrian Lingkungan Hidup dan Kehutanan Republik Indonesia. (2009). UU No.32 Tahun 2009 Tentang Perlindungan dan Pengelolaan Lingkungan Hidup. Jakarta : http://www.menlhk.go.id/site/download .

Weed M. Sport Tourism and the Development of Sport Events UK: www.idrottsforum.org; 2006 [cited 2014]. Available from: http://idrottsforum.org/articles/weed/weed061213.pdf. 